Saudi Journal of Economics and Finance

Abbreviated Key Title: Saudi J Econ Fin ISSN 2523-9414 (Print) |ISSN 2523-6563 (Online) Scholars Middle East Publishers, Dubai, United Arab Emirates Journal homepage: http://saudijournals.com/sjef/

\title{
Nexus between Informal Financial Institutions (IFIs) and Performance of Women Entrepreneurs in Nigeria
}

\author{
Ademola Abimbola $\mathrm{O}^{1 *}$, Adegoke Kolawole $\mathrm{A}^{2}$ and Adegboyegun Adekunle $\mathrm{E}^{3}$ \\ ${ }^{1}$ Department of Accounting and Finance, Landmark University, Omu-Aran Road, Omu-Aran, Nigeria \\ ${ }^{2}$ Department of Banking and Finance, Achievers University, KM 1 ldasen/Uteh Road, Owo, Nigeria \\ ${ }^{3}$ Department of Accounting and Finance, Landmark University, Omu-Aran Road, Omu-Aran, Nigeria
}

\begin{abstract}
DOI: $10.36348 /$ SJEF.2019.v03i09.002
| Received: 20.08.2019| Accepted: 27.08.2019| Published: 11.09.2019
\end{abstract}

*Corresponding author: Ademola Abimbola

\section{Abstract}

The complex application procedures and stringent conditions attached to formal credit financing discourage women entrepreneurs from accessing FFIs. As a result, these entrepreneurs have no alternative but to fall back on IFIs for their credit needs. Consequently, this study seeks to evaluate the nexus between IFIs and performance of women entrepreneurs in Nigeria. It also investigates why IFIs continues to exist alongside the formal financial system, despite the implementation of financial sector reforms. A sample of 348 entrepreneurs was selected using multi-stage sampling technique and data were analysed using frequency and percentages, spearman rank correlation and factor analysis. Findings revealed that IFIs contributes significantly to job creation, accumulation of assets, savings mobilization, poverty alleviation and women entrepreneurship development. Moreover, some of the factors that accounts for the prevalence of IFIs among women entrepreneurs in Nigeria are low interest on loans, no request for collateral, quick response to member's needs, flexible repayment pattern and less government interference in the activities of IFIs. However, insufficient funds, poor record keeping, illiteracy, loans default and delays in assessing credits leads to inefficiency and mismanagement of IFIs in Nigeria. Therefore, it would be important for reforms in FFIs to integrate IFIs to the mainstream of financial sector rather than seeking to eliminate them.

Keywords: Women entrepreneurs, informal financial institutions (IFIs), performance, savings mobilization, Formal financial institutions (FFIs).

Copyright @ 2019: This is an open-access article distributed under the terms of the Creative Commons Attribution license which permits unrestricted use, distribution, and reproduction in any medium for non-commercial use (NonCommercial, or CC-BY-NC) provided the original author and source are credited.

JEL Classification: G21, G23

\section{INTRODUCTION}

Poverty remains a major challenge to sustainable development, environmental security and universal stability [1]. Available statistics revealed that poverty is prevalent in Nigeria and the latest human development programme indicate that $92 \%$ of Nigerian's population especially women live below the poverty line as they subsist on less than US \$2 (\#320) a day [2]. As a result of rising problems of poverty and unemployment, so many people especially women are now engaged in entrepreneurship. Entrepreneurship occupies a strategic position in the growth of an economy especially in developing countries where they are considered as a proven instrument to fight poverty in an effective manner. This is particularly essential to women because it allows for self-employment which gives them an opportunity to fully utilise their capabilities [3].Women entrepreneurship is important for value addition, poverty reduction and increased productivity [4].

However, considering the numerous benefits derived from women entrepreneurship, Sanusi [5] in his recent treatise reported that several barriers hinder the full optimisation of women's economic potential. These range from lack of access to finance, feminization of poverty which is symbolized by large inequalities as cultural and traditional practices constrain equal access to resources, decision on distribution and utilisation of those resources [6]. In order to enhance women entrepreneurship, the three tiers of governments in Nigeria, formal financial institutions (FFIs) and NGOs have offered support to entrepreneurs through financial intermediation, infrastructures and policy measures. 
Regardless of the institutional measures and supports provided so far, women entrepreneurship has not yet reached an acceptable level and their enterprises continue to fall behind that of their male counterparts, they are often limited by many socio-cultural disadvantages due to gender discrimination [7] Most FFIs consider women enterprises as risky and creditunworthy because of their high failure rates. Moreover, the stringent conditions and requirements set by FFIs that include provision of collateral, complicated application procedures and high transaction costs greatly limits their access to credits [8].

Therefore, as a result of the unwillingness of the FFIs to provide financial services to women entrepreneurs, associated with unsustained government and non-governmental sponsored poverty alleviation schemes, women entrepreneurs have no alternative but to turn to informal means of accessing credit to meet their financial needs, both at the household level and as capital for their small scale business enterprises. Informal financial institutions (IFIs) include all classes of credit, savings associations and markets functioning outside the FFIs [9]. IFIs that exist in Nigeria include Isusu, age grade associations, village administration contribution and rural development, men's revolving loan associations, married women's association, town union, local money-lenders and social clubs, etc. Others that are well recognized are fixed fund associations and rotating savings and credit associations.

They contribute enormously to encouraging thrift, communal development and the promotion of education, general business and industry. Communities with many traditional financial institutions manifest a higher level of development due to high volume of savings and investment that are encouraged. In the absence of FFIs, they have constituted the only source for harnessing of funds of the relatively surplus economic units of the rural and urban areas [10].

Regardless of the beneficial effects of IFIs especially at the grassroots, Oloyede [11] found out that their contributions to economic growth are argued to be plagued by several factors such as small financial base, loan default, management problem, poor record keeping and unfavourable government policies. That notwithstanding, it has been clearly established that IFIs are frequently patronized by women entrepreneurs and its use has remained persistently high in Nigeria, therefore this research seeks to examine the salient factors that accounts for the prevalence of IFIs among women entrepreneurs and evaluate the relationship between IFIs and women entrepreneurs' performance in Nigeria.

\section{Statement of the Problem}

One of the main policy objectives of the expansion of formal finance in developing countries is to curtail the use of informal finance because of the associated downsides of its use. However, a number of studies have found that large informal financial sectors still exists in sub-Saharan African economies especially in Nigeria. Howbeit, most of them fail to investigate the factors that are responsible for IFIs continued existence. In order to fill this gap, this study intends to evaluate the factors that account for the prevalence of IFIs in Nigeria and to determine its impact on the performance of women entrepreneurs in Nigeria

\section{Objectives of the Study}

The specific objectives of this research work are to:

- Determine the types of IFIs frequently patronized by women entrepreneurs in Nigeria

- Examine the salient factors that accounts for the prevalence of IFIs among women entrepreneurs

- Evaluate the nexus between IFIs and performance of women entrepreneurs in Nigeria

- Determine the impact of IFIs on the performance of women entrepreneurs in Nigeria

- Investigate the inherent problems associated with the use of IFIs in Nigeria

\section{Hypotheses of the Study}

${ }^{1} \mathrm{H}_{0}$ : There is no relationship between IFIs and performance of women entrepreneurs in Nigeria

${ }^{2} \mathrm{H}_{0}$ : IFIs do not enhance the performance of women entrepreneurs in Nigeria

\section{LITERATURE REVIEW Conceptual Issues \\ Informal financial Institutions}

The Nigerian government established some FFIs including commercial banks, development banks, community banks and microcredit finance banks to provide credit, financial and ancillary support to entrepreneurs in the country. Nevertheless, most of these institutions were bogged down by many factors among which are;

- Discrimination against the poor and the less privileged including women

- High rates of interests

- Complicated application procedures

- Stringent conditions and requirements which the entrepreneurs are unable to meet.

Therefore, as a result of these, majority of the rural poor people especially women resorted to patronizing IFIs. IFIs are age long and ancient institutions whose activities precede those of the FFIs but are not controlled by government [12]. The development of IFIs over the years and a number of success stories recorded have lent credence to the idea that they are power instruments for promoting economic development. They provide significant 
income and create jobs for the less privileged in developing countries. Adamu [13] defined IFIs as collaboration of group of people united to encourage each other to save regularly with a view of providing themselves with credit facilities at accessible interest rate. IFIs include, among others, women self-help groups, family sources, moneylenders and shopkeepers. Saving and loaning is done mainly on trust, with minimal documentation, mostly without any form of security. The amounts loaned or saved are small, frequent and for short durations of time. The default rates are minimal mainly due to group pressure and periodic monitoring meetings.

\section{Concept of Women Entrepreneurship}

Women entrepreneurship is the engagement of women in value creation, setting up businesses and taking on financial risks in order to make ends meet or fulfill their entrepreneurial passion. Women entrepreneurs are simply women that participate in total entrepreneurial activities, who take the risks involved in combining resources together in a peculiar manner so as to benefit of the opportunity identified in their immediate environment through production of goods and services. They are generally motivated in the same way as their men counterparts [14]. However, their activities often range from micro businesses to small and medium enterprises [8].

\section{Empirical Studies}

Studies have reported higher patronage of IFIs among the rural and urban poor, including people with and without regular income [15]. Compared to the formal banking system, these savings organisations are ubiquitous, handling small amount of savings of 'common people' and granting them credits. Their administrative and transactions costs are much lower [16]. Other than the issue of accessibility, explanation for the continual patronage of the informal financial institutions has been found in features such as their effective simple procedures, flexibility, adaptability to local peculiarities and circumstances and multipurpose functions comprising economic and social dimensions [17].

Zaman [18] stressed the significance of IFIs on socio-economic development. He found that IFIs increase entrepreneur's revenue and assets. It plays significant roles in providing insurance against erratic risks facing group members [19]. Moreover, in Bangladesh, Khandker and Khan [20], found out that IFIs increases income and reduces vulnerability. In Nigeria, Ademola et al., [21] further reported that IFIs influenced the performance of women entrepreneurs significantly.

\section{Theoretical Framework}

This research is hinged on Pecking order and dependency theories.

\section{i. Pecking order theory}

This theory was first suggested by Donaldson in 1961 and it was modified by Myers and Majluf in 1984. It attempts to explain why companies prefer to use one type of financing over another. According to this theory, financing comes from three sources, internal funds, debt and new equity. Companies will prefer to use internal financing first, then debt, and finally new equity as the option of last resort. Hence, this theory therefore aligns with the study because women entrepreneurs source internally for finances first because of its accessibility, informality and affordability [22].

\section{ii. Dependency theory}

Gunder Frank propounded the dependency theory borrowing from Marx's ideas. This theory is of the view that rather than emulating the behaviours, attributes and institutions of the developed nations, indigenous institutions should be promoted. They are of the opinion that the major objective of foreign institutions is exclusively profit maximization at the expense of socio-economic development. They take undue advantage of the masses and are involved in capital flight. Accordingly, this theory places value on indigenous institutions like IFIs therefore promoting economic development.

\section{METHODOLOGY}

\section{Population of the Study}

The research was conducted in Oyo state, Nigeria. The state is made up of three senatorial districts and thirty three local Government areas with Ibadan as its capital. Six local governments were purposively selected for the study.

\section{Sample Size and Sampling Procedure}

Multi-stage sampling technique was used to select 348 women entrepreneurs from the total population of 2700 respondents which were initially identified through a preliminary survey. The study focused exclusively on the activities of women entrepreneurs such as Fashion Designers, Hairdressers, Textile Traders and food Caterers. Furthermore, data were analysed using descriptive statistics such as frequency and percentages, tables, charts and spearman rank correlation and factor analysis.

\section{EMPIRICAL RESULTS AND DISCUSSION}

The types of informal finance frequently used by women entrepreneurs in Nigeria are shown in Fig-1 and findings revealed that savings contributions, ROSCAs, group cooperatives and trade credit are sources of informal finance frequently patronized by the entrepreneurs. This is as a result of provision of interest free loans and accessibility of these sources. Respondents also patronized Friends and Relatives sources because they are interest free howbeit, they can't be relied upon and generate small amount of capital relative to the business needs. 
However, the use of moneylenders was minimal, they were the least patronized source of finance, relative to entrepreneur's awareness of them, the respondents reported that their transaction cost and interest rate is high and so can only be approached as a very last resort. This is in line with the findings of Lawal and Abdullahi [23] who asserted that money lender was not frequently patronised because of excessive high interest rates and exploitation through under valuation of collaterals.

Findings revealed that women entrepreneurs prefer sources of finance that are accessible and affordable, though IFIs may not generate large sums of funds to meet the needs of the entrepreneurs. This finding corroborates the assertion of Ademola [22] that many entrepreneurs especially women depend on IFIs like ROSCAs, group cooperatives, savings contributions and so many others to start or grow their businesses.

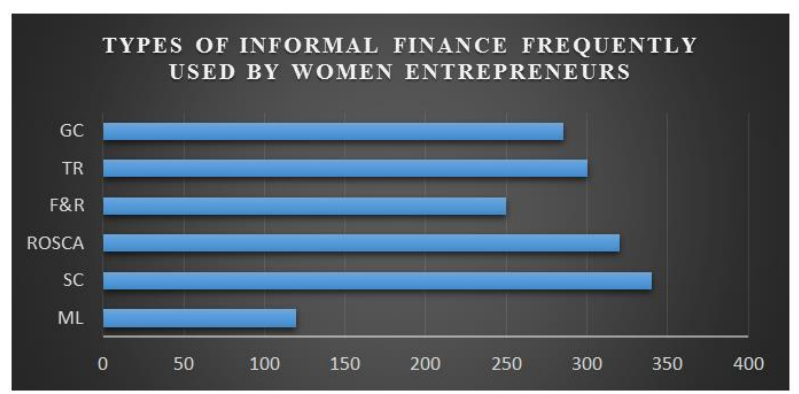

Fig-1: Types of informal finance frequently used by women entrepreneurs in Nigeria Source: Field Survey, 2019

The factors that accounts for prevalence of IFIs among women entrepreneurs were analysed using Factor Analysis. Kaiser-Meyer-Olkin (KMO) was used to measure the adequacy of the samples. Table-5 showed that the KMO measure is 0.693 ; this signifies that the factor analysis is appropriate. Also, the significance value $\mathrm{p}<0.008$ for Sphericity test indicate that the variables are correlated which makes it germane to factor analysis. Thus, the values of the test are considered significant.

Moreover, Table- 6 shows all the factors that are extracted from factor analysis along with their eigenvalues, the percent of variance that is attributed to each factor, the cumulative variance of the factor and the previous factors. The first five factors responsible for the continued existence of IFIs (low interest, no collateral, quick response, flexible repayment pattern and less government interference) accounts for $12.937 \%, 12.537 \%, 12.180 \%, 11.041 \%$ and $10.311 \%$ of the variance respectively.

Findings revealed that interest free loans makes IFIs attractive to entrepreneurs. Most transactions in IFIs do not require collaterals because they take place with close and direct links, both physical and psychological. This allowed them to determine the financial capability and relative risk of the borrower, observe borrowers expenses, and also ensure repayments. This intercepted the need for collateral since transactions takes place on a face-toface basis [24].

Moreover, due to local services, specific borrowers, personified services and close informational links, credit supplied by the IFIs is well timed. It is accessible when most needed and within the shortest possible time. Additionally, the terms and conditions of loans made by IFIs are adjustable. This helps IFIs to respond efficiently to the needs of the entrepreneurs. Furthermore, less government interference is another factor that account for the prevalence of IFIs in Nigeria. Regulations normally imposed on FFIs such as auditing requirements, priority lending, and other rules regarding loan application processing do not apply to IFIs.

Other factors that accounts for continued existence of IFIs in Nigeria are favourable transaction cost, less stringent conditions, less discrimination against women, strong network etc. Ostrom [16] stressed that high interaction rates, proximity and effective mechanisms such as first, second, and thirdparty enforcement make it easier for mutual monitoring among members to occur and helps to minimize the temptation to default. Social capital such as shared norms, networks of relationships, and trust are important factors that explain how these institutions have been able to remain sustainable.

Table-1: KMO and Bartlett's Test

\begin{tabular}{|l|l|r|}
\hline Kaiser-Meyer-Olkin Measure of Sampling Adequacy. & $\mathbf{. 6 9 3}$ \\
\hline Bartlett's Test of Sphericity & Approx. Chi-Square & 70.974 \\
\cline { 2 - 3 } & Df & 45 \\
\cline { 2 - 3 } & Sig. & .008 \\
\hline
\end{tabular}


Table-2: Communalities

\begin{tabular}{|l|l|r|}
\hline & Initial & Extraction \\
\hline Low interest & 1.000 & .706 \\
\hline Strong network & 1.000 & .471 \\
\hline Quick response & 1.000 & .635 \\
\hline Favourable Trans. Cost & 1.000 & .591 \\
\hline Less govt. interf. & 1.000 & .603 \\
\hline Flex. Repay & 1.000 & .615 \\
\hline Less str. Reqt & 1.000 & .569 \\
\hline No collateral & 1.000 & .680 \\
\hline Less discrimn.. & 1.000 & .507 \\
\hline Unwillingness of fin. Inst & 1.000 & .524 \\
\hline
\end{tabular}

Extraction Method: Principal Component Analysis

Table-3: Total Variance

\begin{tabular}{|c|c|c|c|c|c|c|c|}
\hline \multirow[t]{2}{*}{ Component } & \multicolumn{3}{|c|}{ Initial Eigenvalues } & \multicolumn{3}{|c|}{$\begin{array}{llll}\text { Extraction Sums of } & \text { Squared } \\
\text { Loadings }\end{array}$} & \multirow{2}{*}{$\begin{array}{l}\text { Rotation Sums of } \\
\text { Squared Loadings }\end{array}$} \\
\hline & Total & $\begin{array}{c}\% \text { of } \\
\text { variance }\end{array}$ & $\begin{array}{c}\text { Cumulative } \\
\%\end{array}$ & Total & $\begin{array}{c}\% \text { of } \\
\text { variance }\end{array}$ & $\begin{array}{c}\text { Cumulative } \\
\%\end{array}$ & \\
\hline $\begin{array}{l}\text { LOW INTEREST } \\
\text { RATE. }\end{array}$ & 1.294 & 12.937 & 12.937 & 1.294 & 12.937 & 12.937 & 1.267 \\
\hline NO COLLATERAL. & 1.254 & 12.537 & 25.473 & 1.254 & 12.537 & 25.473 & 1.247 \\
\hline QUICK RESPONSE & 1.218 & 12.180 & 37.654 & 1.218 & 12.180 & 37.654 & 1.181 \\
\hline FLEX. REPAYMENT & 1.104 & 11.041 & 48.695 & 1.104 & 11.041 & 48.695 & 1.118 \\
\hline LESS GOVT.INTERF. & 1.031 & 10.311 & 59.005 & 1.031 & 10.311 & 59.005 & 1.109 \\
\hline FAV. TRANS. COST & .925 & 9.255 & 68.260 & & & & \\
\hline $\begin{array}{l}\text { LESS STRINGENT } \\
\text { REQT. }\end{array}$ & .888 & 8.876 & 77.136 & & & & \\
\hline $\begin{array}{l}\text { UNWILLINGNESS } \\
\text { OF FIN. }\end{array}$ & .821 & 8.205 & 85.341 & & & & \\
\hline $\begin{array}{l}\text { LESS } \\
\text { DISCRIMINATION } \\
\end{array}$ & .762 & 7.617 & 92.959 & & & & \\
\hline STRONG NETWORK & .704 & 7.041 & 100.000 & & & & \\
\hline
\end{tabular}

Source: Field Survey, 2019

Spearman rank correlation coefficient was used to examine the nexus between IFIs and performance of women entrepreneurs, the result of the study showed that ROSCAs, group cooperatives and savings collectors correlated significantly and positively with the performance of women entrepreneurs. This may be due to the fact that these sources are flexible and adapt easily to rural and urban peculiarities as well as existing community patterns of groupings and organizing. Also, these sources are indigenous mechanism and techniques employed by the people to identify their felt needs, choose what they want and take cooperative action to satisfy their needs. This finding is in line with Gugerty [25] and Zaman [18] that ROSCAs, group cooperatives and savings collectors play an important role in savings mobilization as they increase revenue and assets acquisition.
Furthermore, trade credit and family and friends sources of finance showed moderate correlation with performance of women entrepreneurs. Trade credit helps to manage short term cash flows. Also, family and friends sources are faster and inexpensive. Though, interest rates and repayment terms are easily adjustable; however, they are not dependable and generate very small amount of capital relative to business needs. In contrast, moneylenders' source of finance showed weak correlation with performance. This may be due to the fact that credit from moneylenders often involves high cost; hence the demand for it usually comes from persons without any other options. However, it is the only source that does not necessitate borrowers to fulfill specific membership commitment. 
Table-4: Spearman Rank Correlation Analysis showing the relationship between Informal finance and performance of women entrepreneurs

\begin{tabular}{|l|l|l|l|l|l|l|l|}
\hline $\begin{array}{l}\text { TYPES OF } \\
\text { INFORMAL } \\
\text { FINANCE }\end{array}$ & $\begin{array}{l}\text { MONEY } \\
\text { LENDERS }\end{array}$ & $\begin{array}{l}\text { FAMILY } \\
\text { MEMBERS }\end{array}$ & $\begin{array}{l}\text { GROUP } \\
\text { COOP }\end{array}$ & ROSCA & $\begin{array}{l}\text { SAVINGS } \\
\text { COLLECTORS }\end{array}$ & $\begin{array}{l}\text { TRADE } \\
\text { CREDIT }\end{array}$ & PERFORM \\
\hline MONEY LENDERS & 1.0000 & & & & & & \\
\hline $\begin{array}{l}\text { FAMILY } \\
\text { MEMBERS }\end{array}$ & 0.1207 & 1.0000 & & & & & \\
\hline GROUP COOP & 0.0317 & 0.0224 & 1.0000 & & & & \\
\hline ROSCA & 0.0641 & 0.2271 & 0.7768 & 1.0000 & & & \\
\hline $\begin{array}{l}\text { SAVINGS } \\
\text { COLLECTORS }\end{array}$ & 0.2255 & 0.3422 & 0.7480 & 0.5795 & 1.0000 & & \\
\hline TRADE CREDIT & 0.3820 & 0.1910 & 0.0313 & 0.2114 & 0.2230 & 1.0000 & \\
\hline PERFORMANCE & 0.0502 & 0.2667 & 0.7006 & 0.7280 & 0.5147 & 0.3079 & 1.0000 \\
\hline
\end{tabular}

***Correlation is significant at 0.01 level ( 2 tailed)

Source: Field survey, 2019

Table-5 shows the turnover performance of the enterprises surveyed in the three years prior to this study. This was done on the basis of yearly averages of each of the three surveyed classes of enterprises. Between 2016 and 2017, all the enterprises showed a steady rise in gross turnover, although this trend showed that on the average, each enterprise surveyed recorded an increase in gross earning which reflects an improved performance by the enterprise.

Moreover, when the rate at which gross earnings rose between 2016 and 2017 was compared with the rate at which they rose between 2017 and 2018, it is evident that the enterprises performed relatively better in 2018 than they did in 2017. This may be attributed to the fact that majority of these entrepreneurs belongs to cooperative societies, ROSCAs and also participate in contribution schemes from where they source finance for their businesses. These sources are accessible and interest free. Furthermore, the results indicated that IFIs impacted significantly and positively on the performance of the enterprises.

Table-5: Impact of informal finance on performance of women entrepreneurs using Average Gross Turnover (2016-2018)

\begin{tabular}{|l|l|c|c|c|l|c|}
\hline Sector & $\begin{array}{l}\mathbf{2 0 1 6} \\
\text { \#'000 }\end{array}$ & $\begin{array}{c}\text { Rate of change } \\
(\mathbf{\%})\end{array}$ & $\begin{array}{c}\mathbf{2 0 1 7} \\
\text { \#'000 }\end{array}$ & $\begin{array}{c}\text { Rate of change } \\
(\mathbf{\%})\end{array}$ & $\begin{array}{l}\mathbf{2 0 1 8} \\
\text { \#'000 }\end{array}$ & $\begin{array}{c}\text { Rate of change } \\
(\boldsymbol{\%})\end{array}$ \\
\hline Trading & 450 & - & 510 & 13.33 & 580 & 13.72 \\
\hline Catering & 370 & - & 425 & 14.86 & 489 & 15.01 \\
\hline Hairdressing & 380 & - & 435 & 14.47 & 498 & 14.48 \\
\hline Fashion Designing & 385 & - & 440 & 14.29 & 505 & 14.77 \\
\hline
\end{tabular}

Source: Field Survey, 2019

The challenges militating against IFIs are revealed in Table-6, findings showed that almost all the respondents ( 97.70 percent) asserted that insufficient funds is the most prominent challenge facing IFIs in Nigeria. From this study, it is obvious that funds are grossly inadequate for the entrepreneurs. This is because entrepreneurs' propensity to save for the growth of their enterprises is very low due to the low income derived from their enterprises [26]. As a result of this; there are possibilities that disbursements from IFIs may be insufficient to achieve the planned investment opportunity.

Also following closely is poor record keeping, illiteracy, loans default and delays in assessing credits. These factors hinder the effective functioning of IFIs in Nigeria. Majority of IFIs do not keep records of their operations because they have no legal backing and are not guided by good accounting procedures. Poor record keeping and illiteracy leads to inefficiency and mismanagement of IFIs.
Moreover, default by members often lead to uncertainty that can stem from the possibility of a low payout from the IFIs arising from the depletion of members. Adeoye [27], Yusuf et al., [28] and Adofu et al., [29] buttressed this assertion that risk of default is a serious concern for IFIs and total abscondment by the collector of money with the proceeds of collection without any means of insurance coverage also constitute a serious threat to IFIs development in Nigeria.

Poor administration and organization is another problem facing IFIs in Nigeria, if IFIs are well organized with good leaders in administration, then IFIs will succeed. This finding tallies with the report of Onuohia [30] who identified leadership problems as challenges that make progress more difficult for IFIs. Also, Akinwumi [31] affirmed that bad leadership is a critical element that affects efficiency of IFIs in Nigeria. Others are ignorance, poverty mentality, 
favouritism, poor monitoring of loans and harsh loan recovery methods. All these factors if not managed well could lead to poor performance and decline of IFIs.

Table-6: Problems militating against informal sources of finance

\begin{tabular}{|l|l|c|c|}
\hline S/N & Problems militating against informal sources of finance & Frequency & \% \\
\hline 1. & Poor record keeping & 305 & 87.64 \\
\hline 2. & Poor Administration and Organisation & 280 & 80.46 \\
\hline 3. & Illiteracy & 300 & 86.20 \\
\hline 4. & Insufficient funds & 340 & 97.70 \\
\hline 5. & Loans default & 300 & 86.20 \\
\hline 6. & Delay in Assessing credits & 295 & 84.77 \\
\hline 7. & Poor monitoring of loans & 270 & 77.59 \\
\hline 8. & Harsh loan recovery methods & 120 & 34.48 \\
\hline 9. & Poverty Mentality & 200 & 57.47 \\
\hline 10. & Ignorance & 275 & 79.02 \\
\hline 11. & Favouritism & 200 & 57.47 \\
\hline
\end{tabular}

Source: Field Survey, 2019

\section{Summary of Findings}

Majority of the women entrepreneurs frequently patronize savings contributions, ROSCAs, group cooperatives and trade credit however the use of moneylenders is minimal due to high rate of interest and exploitation.

The salient factors responsible for the continued existence of IFIs are no/low interest on loans, no request for collateral, quick response to member's needs, flexible repayment pattern and less government interference in the activities of IFIs.

ROSCAs, group cooperatives and savings collectors correlated significantly and positively with the performance of women entrepreneurs, trade credit and family and friends showed moderate correlation while moneylenders showed weak correlation with performance of women.

IFIs impacted significantly and positively on the performance of the enterprises; however, major problems besetting the performance of IFIs are insufficient funds, poor record keeping, illiteracy, loans default and delays in assessing credits. All these factors and many more leads to inefficiency and mismanagement of IFIs.

\section{CONCLUSION AND RECOMMENDATION}

The complex application procedures and stringent conditions attached to formal credit financing discourages women entrepreneurs from accessing formal financial institutions. As a result, these entrepreneurs have no alternative but to fall back on IFIs for their credit needs. Consequently, this study seeks to evaluate the nexus between IFIs and performance of women entrepreneurs in Nigeria. It also investigates why IFIs continues to exist alongside the formal financial system, despite the implementation of financial sector reforms. Moreover, the challenges facing IFIs were critically examined.
A sample of 348 entrepreneurs was selected using multi-stage sampling technique and data were analysed using descriptive statistics such as frequency and percentages, tables, charts, spearman rank correlation and factor analysis. Based on these findings, it is evident that IFIs contributes significantly to job creation, accumulation of assets, savings mobilization, poverty alleviation and women entrepreneurship development.

Moreover, some of the factors that accounts for the prevalence of IFIs among women entrepreneurs in Nigeria are low interest on loans, no request for collateral, quick response to member's needs, flexible repayment pattern and less government interference in the activities of IFIs. However, insufficient funds, poor record keeping, illiteracy, loans default and delays in assessing credits leads to inefficiency and mismanagement of IFIs in Nigeria.

This study therefore recommends that government should collaborate with stakeholders and come up with a policy and backed up by legislation to ensure that funds are available to women entrepreneurship through cooperative societies, microfinance banks, commercial banks and bank of industry. Moreover, it would be important for reforms in FFIs to integrate informal finance to the mainstream of financial sector rather than seeking to eliminate them. Future studies should also try to establish the linkages between formal and informal finance in Nigeria in order to determine whether they are complementary or substitutes.

\section{REFERENCES}

1. World Business Council for Sustainable Development WBCSD. (2007). http://www.wbcsd.org/web/development.html, accessed on 20/02/09.

2. United Nations Development Programme (UNDP). (2011). Human Development Report, United Nations, Washington D.C. 
3. Wasihun, R., \& Paul, I. (2010). Growth determinants of women operated micro and small enterprises in Addis Ababa. Journal of sustainable Development in Africa, 12(6), 233-246.

4. Singh, G., \& Belwal, R. (2008). Entrepreneurship and SMEs in Ethiopia: Evaluating the role, prospects and problems faced by women in this emergent sector. Gender in management: An international journal, 23(2), 120-136.

5. Sanusi, S. L. (2012). Increasing Women's Access to Finance: Challenges and Opportunities. Paper presented by Mr Sanusi Lamido Sanusi, Governor of the Central Bank of Nigeria, at the Second African Women's Economic Summit, Lagos, 13 July 2012.

6. World Bank. (2007). Doing Business: How to Reform. Washington, D.C. The International Bank for Reconstruction and Development.

7. UNIFEM (2002). Working for Women 1 s Empowerment and Gender Equality. New York, USA: United Nations Development Fund for Women, UNIFEM.

8. International Labour Organization. (1998). Women in the Informal Sector and their access to Micro-finance. Paper presented at the InterParliamentary Union (IPU) Annual Conference. Windhoek, Namibia.

9. Umebali, E. E. (1996). Agric business and financial analysis. Enugu: Computer Edge Publishers. World Bank, Nigeria, Poverty in the Midst of Plenty: The challenge of Growth with Inclusion Washington, D. C. World Bank; 2002.

10. Onoh, J. K. (2002). Dynamics of money, banking and finance in Nigeria. An Emerging Market. 2nd reprint. Aba Astra Meridian Publishers.

11. Oloyede, J. A. (2008). Informal financial sector, savings mobilization and rural development in Nigeria: Further evidence from Ekiti state of Nigeria. African Economic and Business Review, 6(1), 35-63.

12. Iganiga, B. O., \& Asemota, A. (2008). The Nigerian unorganized rural financial institutions and operations: A framework for improved rural credit schemes in a fragile environment. Journal of Social Sciences, 17(1), 63-71.

13. Adam, G. (2007). Role of microfinance institutions in actualization of MDGs. Paper delivered at the induction ceremony of Institute of Chartered Economists of Nigeria (ICEN) in Port Harcourt.

14. Kerta, S. (1993). Women and Entrepreneurship, ERIC Digests.

15. Ojo, J. A. T. (1992). Reforming the Nigerian financial system for industrial transformation. Proceedings of the 1st Annual Conference of the Nigerian Society for Financial Research.

16. Ostrom, E. (1999). Context and Collective Action: Four Interactive building blocks for a family of explanatory theories. Paper presented at the
Workshop on Political Theory and Policy Analysis, Indiana University.

17. Ojo, A. T. (1995). Informal Financial Institutions: Nature, Characteristics and Operations, Paper presented at the Technical Workshop on Conceptual and Methodological Issues in the Informal Financial Sector Research, held at NISER, Ibadan, August 30, and 31, 1995.

18. Zaman, H. 1999. Assessing the Impact of Microcredit on Poverty and Vulnerability in Bangladesh. World Bank policy Research Working Paper No. 2145.

19. Aryeetey, E., \& Udry, C. (1995). The Characteristics of Informal Financial Markets in Africa. Paper presented at the Plenary Session of the Bi-annual Research Conference of the African Economic Research Consortium, Nairobi, Kenya.

20. Khandker, S., \& Khan, J. O. (1998). Fighting Poverty Microcredit. Dhaka, Bangladesh: University Press Limited.

21. Ademola, A., Oyeleye, O., \& Afolabi, O. (2013). Performance evaluation of Cooperative Societies on women entrepreneurs in Nigeria. Elixir Journal Finance Management, 65, 19900-19904.

22. Ademola, A. O. (2016). Performance impact of non-institutional factors and financial management practices on women-owned microenterprises in Oyo state. Ph.D. Thesis, Ladoke Akintola University of Technology, Ogbomoso.

23. Lawal, W. A., \& Abdullahi, I. B. (2011). Impact of informal agricultural financing on agricultural production in the rural economy of Kwara State, Nigeria. International Journal of Business and Social Science, 2(19), 241-248.

24. Srinivas, H. (2016). 14 reasons why informal credit market is used by the poor. Policy implications for micro credit programmes in Developing countries. GDRC Research output Kobe, Japan: Global Development research centre. Retrieved from http://www.gdrc.org/icm/14reason. html on24 August 2019

25. Gugerty, M. K. (2007). You can't save alone: Commitment in rotating savings and credit associations in Kenya. Economic Development and cultural change, 55(2), 251-282.

26. Ademola, A. O. (2013). Strategic effect of socioeconomic and financial factors on the performance of women entrepreneurs in South Western Nigeria. Elixir International Journal Finance Management, 63, 18455-18459.

27. Adeoye, P. B. (2005). Informal financial sector and poverty alleviation. In Proceedings of the National Conference on Informal Financial Sector and Sustainable Development in Nigeria. Department of Banking and Finance, University of Ado-Ekiti, Ado-Ekiti, Ekiti State, Nigeria (pp. 9396).

28. Yusuf, N., Ijaiya, G. T., \& Ijaiya, M. A. (2009). Informal financial institutions and poverty 
reduction in the informal sector of Offa town, Kwara state: A case study of rotating savings and credit associations (ROSCAs). Journal of Social Sciences, 20(1), 71-81.

29. Adofu, I. A., Antai, E., \& Alabi, O. (2010). Informal Savings Mobilization and Investment: A Case Study of Rotating Savings and Credit Associations (ROSCA) in Kogi State, Nigeria. Continental Journal of Social Sciences, 3, 7.
30. Onuoha, E. (1986). Principles of cooperative enterprise, Enugu Nigeria, Express publishing Company Ltd.

31. Akinwumi, J. (2016). Road map to re-engineering Cooperatives in Nigeria; A paper presented at the South west cooperatives leader conference, organized by cooperative federation of Nigerian South west Zone at Obisesan Hall, Ibadan, Septemberr $7^{\text {th }}, 2006$. 